\title{
Rheological Characterization Bovine Serum Albumin Gels Induced by High Hydrostatic Pressure
}

\author{
Serena De Maria1, Giovanna Ferrari1,2, Paola Maresca ${ }^{2}$ \\ ${ }^{1}$ Department of Industrial Engineering, University of Salerno, Fisciano (SA), Italy \\ ${ }^{2}$ ProdAl Scarl, Fisciano (SA), Italy \\ Email: sdemaria@unisa.it
}

Received 23 April 2015; accepted 9 June 2015; published 12 June 2015

Copyright (C) 2015 by authors and Scientific Research Publishing Inc.

This work is licensed under the Creative Commons Attribution International License (CC BY).

http://creativecommons.org/licenses/by/4.0/

c) (i) Open Access

\begin{abstract}
Similarly to heating, non-thermal technologies like High Hydrostatic Pressure (HHP) are able to affect the native conformation of proteins, causing denaturation, aggregation or gelation. The aim of this work is to evaluate the effect of product's chemical-physical characteristics, namely pH and protein concentration, and process parameters, namely pressure level and processing time, on the stability of the structure of a particular allergen, the Bovine Serum Albumin (BSA) as well as to individuate the most appropriate processing conditions to induce protein denaturation and/or aggregation. Different amounts of BSA protein were dissolved in phosphate buffer $(50 \mathrm{mM})$ at three different $\mathrm{pH}(6,7$ and 8), to obtain concentration levels of $12,25,50$ and $100 \mathrm{mg} / \mathrm{mL}$. The HHP process was carried out at pressure levels in the range between 700 and $900 \mathrm{MPa}$ and treatment time of 15 - 25 min. The structural characteristics of HHP-treated BSA suspensions were assessed by means of a complete rheological screening (strain sweep, frequency sweep and temperature ramp tests) in dynamic regime. Experimental data demonstrate that the rheological parameters, namely the loss and the storage moduli, increase as pressure levels and processing time increase, especially at higher concentrations, whereas a constant critical strain of about $0.3 \%$ is detected. The $\mathrm{pH}$ and protein concentration mainly control the denaturation influencing the threshold value of the processing conditions at which the gelation occurs. At processing conditions below the threshold values, however, the structure of BSA can be reversibly damaged.
\end{abstract}

\section{Keywords}

High Hydrostatic Pressure, BSA, Rheology 


\section{Introduction}

High Hydrostatic Pressure (HHP) processing is a non-thermal technology, applied either to inactivate spoiling microorganisms or prolong foods shelf life, or to induce structural and functional modifications of foods and biomolecules.

It is well known that HHP process can affect protein conformation. This effect depends on several factors related to the compound characteristics, namely the nature of the protein, as well as to processing conditions, namely the applied pressure, temperature level and time [1].

In general, the protein structures (primary, secondary, tertiary and quaternary) are stabilized by covalent bonds, electrostatic interactions, hydrogen bonds and hydrophilic interactions. The HHP process causes the alteration of the structures which are stabilized by hydrophobic interactions, namely the quaternary, the tertiary (reversible unfolding), and secondary structures (irreversible unfolding). In the case of globular proteins, such as albumin, their structural properties are related to the optimum packing of the hydrophobic core, the minimum hydrophobic surface area and ion pairs within and between subunits [2]-[4]. Therefore, since HHP process affects both the tertiary and quaternary structures of globular proteins [5], it is able to promote the dissociation and assembly of systems with higher complexity on one hand, and the unfolding and disassembly on the other hand [6]. The mechanism of pressure-induced unfolding and denaturation of several proteins has not been elucidated yet, but it has been hypothesized that it takes place through reversible unfolding steps as described in the following. When pressure is applied, the intermediates formed play an important role in the aggregation upon the depressurization phase. Pressure-induced conformations are more susceptible to aggregation since the hydrogen bonds can be formed at lower temperatures under pressure [7].

Pressure-induced denaturation can be reversible [8], depending on the kind of protein and concentration and treatment conditions (temperature, time and pressure) [9]. Low protein concentrations and pressure levels up to 200 - $300 \mathrm{MPa}$ usually result in reversible denaturation. Higher pressure levels, above $300 \mathrm{MPa}$, irreversibly and extensively affect proteins, even causing denaturation, due to the unfolding of monomers, the aggregation and gel formation [10]. Protein unfolding is much less intense in HHP processes carried out at moderate conditions than in thermal treatments [11]. Nevertheless, the application of ultra high pressure (1000 MPa) causes a more severe denaturation of various animal proteins than thermal processes [12]. The denaturation rate of proteins is reduced at moderate pressure $(<100 \mathrm{MPa})$ since the generation of hydrophobic interactions, which are responsible for the stability of the helical structure, is favored. Hydrophobic interactions are prevented at pressure levels lower than $1000 \mathrm{MPa}$, causing a volume increase, while they contribute to stabilizing the protein structure at pressure levels higher than $1000 \mathrm{MPa}$.

In the literature several studies reported the gelling of different proteins such as ovalbumin [13] [14], fish protein [5] and meat protein [13] [15] under the effect of pressure and the improvement of some rheological properties in pressure-induced gels. The mechanism of the protein gelation differs according to the protein species, their state and gel-forming ability as well as on pressure-time-temperature combinations [16]-[18]. HHP gels of whey proteins are well known and studied in the scientific literature. Van Camp \& Huyghebaert, for instance, demonstrated that HHP whey proteins gels were very different from heat-induced protein gels in terms of strength and appearance. HHP gels were less strong and surrounded by non-incorporated liquid after pressurization while heat-induced gels were stronger and appeared dry and firm without significant loss of liquid. Structural changes of globular BSA processed in the pressure range between 300 and $500 \mathrm{MPa}$ have been reported, for the onset of denaturation of single-chain proteins. Hayakawa and his co-workers reported a partial denaturation of BSA at pressures levels up to $400 \mathrm{MPa}$ [19].

The aim of this work was to analyze deeply the effects of HHP process on the denaturation/aggregation of a particular protein, the Bovine Serum Albumin, representing the major allergen in beef and beef product, and also present in cow milk and responsible of allergic reactions to this product. In order to assess the modification of the structure of the protein, a complete rheological characterization in dynamic regime was carried out. Product (protein concentration) and process parameters ( $\mathrm{pH}$, operating pressure and time) were changed to determine the processing conditions inducing protein denaturation and/or aggregation phenomena.

\section{Materials and Methods}

\subsection{Preparation of the Samples}

Bovine Serum Albumin (BSA) (Sigma-Aldrich, Italy) samples were prepared according to Penãs et al. [20]. 
BSA was dissolved in a $50 \mathrm{mM}$ Sodium Phosphate Buffer, kept at $25^{\circ} \mathrm{C}$, at different concentrations $(12,25,50$ and $100 \mathrm{mg} / \mathrm{mL}$ ) under gentle mixing until a homogenous solution was obtained. The $\mathrm{pH}$ of the protein solutions was reduced with $\mathrm{HCl}$ and measured with a laboratory $\mathrm{pH}$-meter in order to achieve the desired value. The protein solutions were stored under refrigerated conditions $\left(4^{\circ} \mathrm{C}\right)$ before being processed by HHP.

\subsection{Experimental Apparatus}

The HHP system U22 (Institute of High Pressure Physics, Polish Academy of Science, Unipress Equipment Division, Poland) was used in the experimental campaign. The laboratory scale U22 unit holds a high pressure vessel with a maximum processing volume of $50 \mathrm{~mL}$ and can be operated in a wide pressure range between 0 and $1400 \mathrm{MPa}$, and under thermal controlled conditions $\left(0^{\circ} \mathrm{C}-120^{\circ} \mathrm{C}\right)$. A control panel allows to set-up the operating pressure, the ramp rate and the processing time, as well as to control the opening and the closure of the HHP vessel. The temperature in the HHP vessel is set-up and controlled by a portable Temperature Power and control Unit (TCU) connected to the main unit with K-type thermocouples cables. The vessel is provided by electrical heaters to increase the temperature during treatment while the cooling of the vessel is obtained with compressed air. The pressure medium is Plexol(Bis(2-ethylhexyl)sebacate from Sigma-Aldrich, Italy) and the estimated temperature increase, due to pressure build-up, is $2^{\circ} \mathrm{C}-3^{\circ} \mathrm{C} / 100 \mathrm{MPa}$.

\subsection{Experimental Protocol}

For each experiment, BSA samples $(5 \mathrm{~mL})$ were sealed in flexible pouches of a multilayer polymer/aluminium/ polymer film (Polyethylene-Aluminium-Polypropylene). The pouches were introduced into the U22 vessel and the pressure cycle was set at the desired conditions. All the experiments were conducted at ambient temperature while the pressure was varied in the range between 500 and $900 \mathrm{MPa}$ and the operating time between 15 and 25 $\min$. At the end of the treatment, the pouches were stored at $4^{\circ} \mathrm{C}$ before undergoing the rheological characterization.

\subsection{Rheological Characterization}

A rheometer AR 2000 (TA Instruments, New Castle, DE) was used to detect the structural changes of BSA protein after HHP treatments. Several rheological tests were carried out in dynamic-oscillating regime. A plate-cone measuring geometry was used ( $40 \mathrm{~mm}$ diameter, $2^{\circ}$ ), with a gap width of $1 \mathrm{~mm}$. Samples were loaded onto the rheometer plate and allowed to equilibrate to the measuring temperature $\left(25^{\circ} \mathrm{C}\right)$ for $10 \mathrm{~min}$. Different protocols were used to determine the rheological behaviour of BSA samples

\subsubsection{Strain Sweep Tests}

Preliminary strain sweep tests were carried out in order to individuate the linear viscoelastic region of BSA protein dissolved at two different concentration of 50 and $100 \mathrm{mg} / \mathrm{mL}$ in phosphate solution after HHP treatments at $700 \mathrm{MPa}$ and $900 \mathrm{MPa}$ for 15 and $25 \mathrm{~min}$. Storage (G') and loss (G”) moduli were recorded as a function of the strain, in a range between $0.01 \%$ and $10 \%$, at a constant angular frequency of $6.3 \mathrm{rad} / \mathrm{s}$ and at a fixed temperature of $25^{\circ} \mathrm{C}$.

\subsubsection{Frequency Sweep Tests}

The protein structure has been further characterized by means of frequency sweep tests at a strain below the critical value. The tests were carried out on BSA samples at a concentration of $50 \mathrm{mg} / \mathrm{mL}$ after HHP treatments at $700 \mathrm{MPa}$ and $900 \mathrm{MPa}$ for $25 \mathrm{~min}$. The trends of G' and G' moduli were measured in the angular frequency range between 1 and $100 \mathrm{rad} / \mathrm{s}$ at a fixed strain of $0.1 \%$, lower than critical value, which, in turn, is from the corresponding strain sweep tests conducted on samples treated in the same HHP processing conditions.

\subsubsection{Temperature Ramp Tests}

The protein structure has been further characterized by means of frequency sweep tests at a strain below the critical value. The tests were carried out on BSA samples at a concentration of $50 \mathrm{mg} / \mathrm{mL}$ after HHP treatments at $700 \mathrm{MPa}$ and $900 \mathrm{MPa}$ for $25 \mathrm{~min}$. The trends of G' and G'” moduli were measured in the angular frequency range between 1 and $100 \mathrm{rad} / \mathrm{s}$ at a fixed strain of To assess the effect of temperature increase on the structural 
properties of proteins, dynamic temperature ramp tests were carried out on BSA samples of different concentration, namely 12, 25, 50 and $100 \mathrm{mg} / \mathrm{mL}$, treated by HHP at $500 \mathrm{MPa}$ and $700 \mathrm{MPa}$. The rheological tests were conducted in the temperature range between $25^{\circ} \mathrm{C}$ to $95^{\circ} \mathrm{C}$ utilizing at a ramp rate of $1.5^{\circ} \mathrm{C} / \mathrm{min}$, at a constant strain of $0.1 \%$ and angular frequency of $6.3 \mathrm{rad} / \mathrm{s}$. The trends of G' and G'” moduli were recorded as a function of temperature and the transition phase temperatures were individuated in the graphs.

\section{Results and Discussion}

\subsection{Preliminary Observations}

In Figure 1 the pictures of BSA samples at $\mathrm{pH}=8$ treated at several processing conditions namely pressure level in the range between 600 and $900 \mathrm{MPa}$ (at a treatment time of $25 \mathrm{~min}$ )and protein concentration of 50 and 100 $\mathrm{mg} / \mathrm{mL}$, are reported. It can be observed that more compact gels are obtained at the highest pressure level of 900 MPa and protein concentration of $100 \mathrm{mg} / \mathrm{mL}$. At lower pressures such as $600 \mathrm{MPa}$ proteins denaturation and aggregation occur with increasing the protein concentration, from 50 to $100 \mathrm{mg} / \mathrm{mL}$.

\subsection{Strain Sweep Tests}

The results of strain sweep tests carried out on HHP treated BSA samples were used to evaluate the limits of the viscoelasticity region in which the rheological parameters, such as viscosity or loss and storage moduli, are independent from the strain. These limits may be influenced by the processing parameters (namely pressure level and treatment time) and protein concentration.

The storage or elastic modulus, G', and the loss or viscous modulus, G', can be only defined in the linear viscoelasticity region, while outside it they have no physical meaning. When the sample is subjected to high strains, the stress response of a viscoelastic material is no longer sinusoidal and, consequently, the stress-strain relationship cannot be described in terms of the strain-independent storage and loss moduli, due to higher harmonic contributions [21].

Rheological tests in the dynamic regime were carried out on BSA samples dispersed in sodium phosphate buffer at different concentrations of 50 and $100 \mathrm{mg} / \mathrm{mL}$, processed at pressure levels between 600 and $900 \mathrm{MPa}$ and two different holding times: 15 and 25 min. The experimental results were reported in terms of G' and G' moduli values as a function of the strain (\%), as shown in Figure 2(a) and Figure 2(b) and Figure 3(a) and Figure 3(b). Both storage (Figure 2(a)) and loss moduli (Figure 2(b)) increase with increasing the pressure applied, independently of the treatment times. This behaviour can be attributed to aggregation and coagulation phenomena of proteins taking place as already observed by Apichartsrangkoon et al. [2] for soy protein gels and Aguilar et al. (2007) [22], for egg yolk gels. As the holding times of the samples treated under high pressure conditions is increased, a slightly higher values of G' and G' moduli is observed, especially in the samples with the highest protein concentration. In fact, by prolonging the holding time of the protein under high pressure conditions, more drastic denaturation is likely to occur.

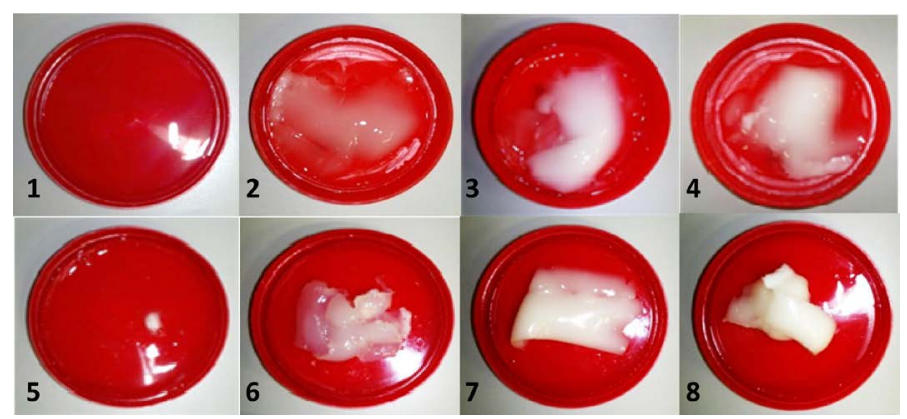

Figure 1. Example pictures of the BSA samples suspended in sodium phosphate buffer (50 mM, pH: 8) treated at different pressures and concentrations. Processing conditions: 1) P $=600 \mathrm{MPa}, \mathrm{t}=25 \mathrm{~min}, \mathrm{c}_{\mathrm{p}}$ $=50 \mathrm{mg} / \mathrm{mL}$; 2) $\mathrm{P}=700 \mathrm{MPa}, \mathrm{t}=25 \mathrm{~min}, \mathrm{c}_{\mathrm{p}}=50 \mathrm{mg} / \mathrm{mL}$; 3) P $=800 \mathrm{MPa}, \mathrm{t}=25 \mathrm{~min}, \mathrm{c}_{\mathrm{p}}=50 \mathrm{mg} / \mathrm{mL}$; 4) $\mathrm{P}=900 \mathrm{MPa}, \mathrm{t}=25 \mathrm{~min}, \mathrm{c}_{\mathrm{p}}=50 \mathrm{mg} / \mathrm{mL}$; 5) $\mathrm{P}=600 \mathrm{MPa}, \mathrm{t}=25 \mathrm{~min}, \mathrm{c}_{\mathrm{p}}=100 \mathrm{mg} / \mathrm{mL}$; 6) $\mathrm{P}=700$ $\mathrm{MPa}, \mathrm{t}=25 \mathrm{~min}, \mathrm{c}_{\mathrm{p}}=100 \mathrm{mg} / \mathrm{mL}$; 7) $\mathrm{P}=800 \mathrm{MPa}, \mathrm{t}=25 \mathrm{~min}, \mathrm{c}_{\mathrm{p}}=100 \mathrm{mg} / \mathrm{mL}$; 8) $\mathrm{P}=900 \mathrm{MPa}, \mathrm{t}=$ $25 \mathrm{~min}, \mathrm{c}_{\mathrm{p}}=100 \mathrm{mg} / \mathrm{mL}$. 


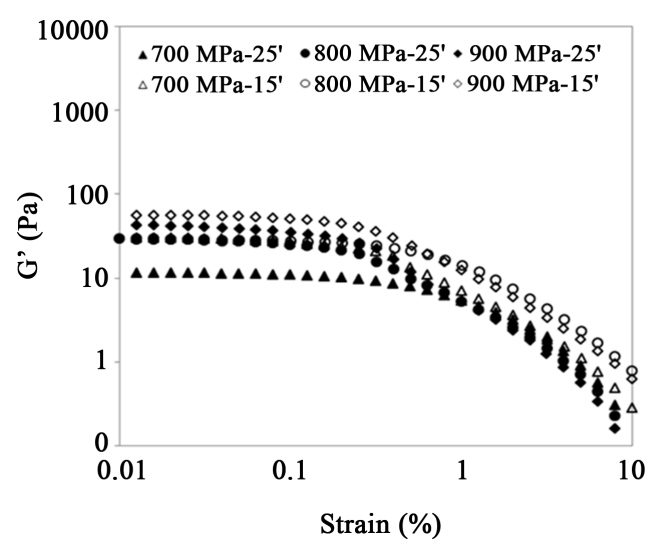

(a)

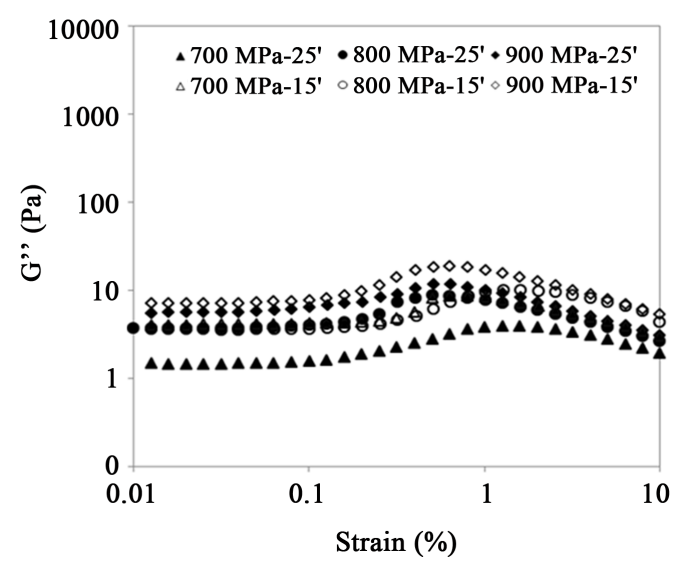

(b)

Figure 2. Strain sweep tests: storage, G' (a) and loss, G” (b) moduli as a function of strain. BSA protein samples suspended in sodium phosphate buffer ( $\mathrm{pH}: 8,50 \mathrm{mg} / \mathrm{mL}$ ) treated at different pressure levels (700 MPa, $800 \mathrm{MPa}$, $900 \mathrm{MPa})$ and treatment times $(15,25 \mathrm{~min})$.

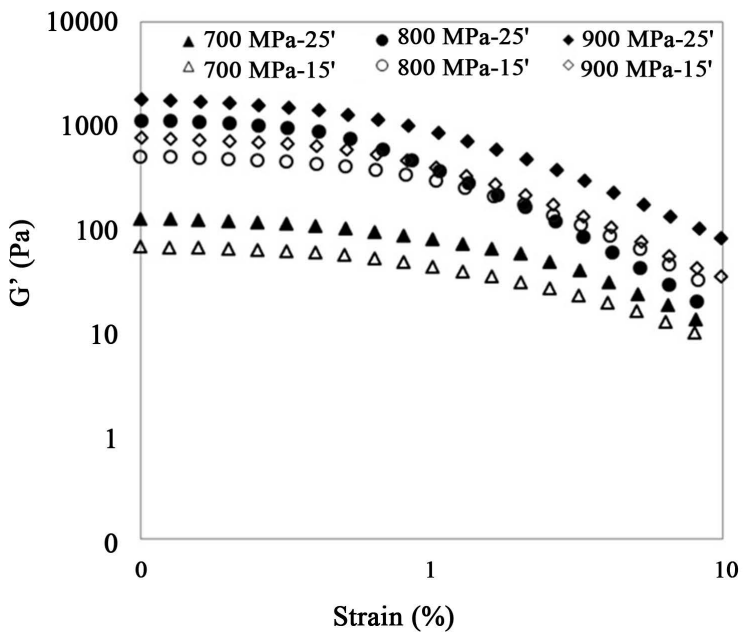

(a)

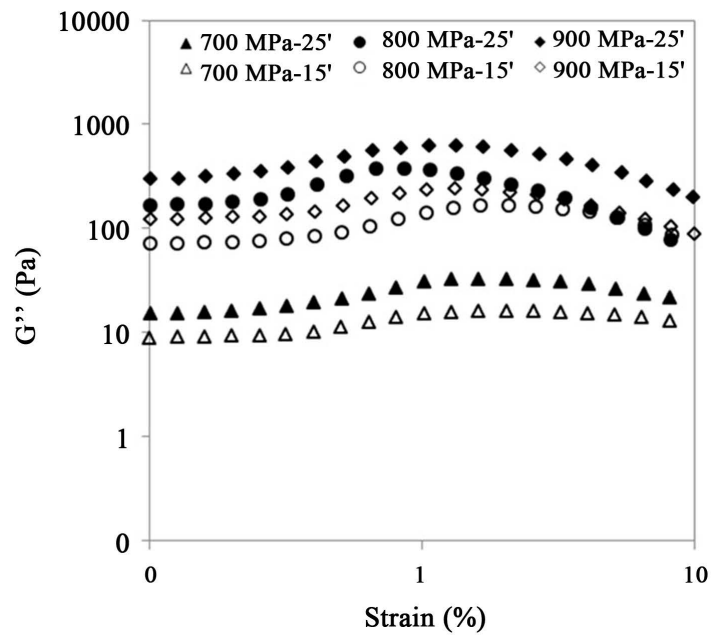

(b)

Figure 3. Strain sweep tests: storage, G' (a) and loss; G” (b) moduli as a function of strain. BSA protein samples suspended in sodium phosphate buffer (pH: 8, $100 \mathrm{mg} / \mathrm{mL}$ ) treated at different pressure levels (700 MPa, $800 \mathrm{MPa}, 900 \mathrm{MPa})$ and treatment times $(15,25 \mathrm{~min})$.

Protein concentration mainly influences the values of the storage and loss moduli. Indeed, if the protein concentration increases from $50 \mathrm{mg} / \mathrm{mL}$ to $100 \mathrm{mg} / \mathrm{mL}$, the values of G' modulus of samples processed at $900 \mathrm{MPa}$ increase of one order of magnitude, passing from values less than 100 (Figure 2(a)) to more than 1000 (Figure 3(a)). A similar trend is observed for G'" modulus, as shown in Figure 2(b) and Figure 3(b). Higher values of protein concentration enhance the formation of both short and long terms bindings, due to the availability of more contact points between neighboring polypeptide side chains [23]. Moreover, the storage modulus is always prevailing with respect to the loss modulus, this indicating that the elastic behaviour of the samples is more relevant than the viscous one (Figure 2(a) and Figure 2(b), Figure 3(a) and Figure 3(b)).

The experimental data of the strain sweep tests were worked out in order to individuate the limits of linear viscoelasticity region that seems to be not significantly affected by processing parameters and protein concentration even though higher values of the critical strains are reached higher concentration $(100 \mathrm{mg} / \mathrm{mL})$ and shorter treatment times (15 min), where aggregation is maximized but a lower gelling phenomena reversibility can be observed. Thus, the estimated values of the critical strain $\left(\gamma_{c}\right)$ and critical stress $\left(\tau_{c}\right)$ of the linear region of viscoelasticity at different pressures are listed in Table 1 . At strain values lower than about $0.3 \%$, a linear region is 
Table 1. Critical storage modulus $\left(\tau_{c}\right)$ and strain $\left(\gamma_{c}\right)$ measured for BSA $(50 \mathrm{mg} / \mathrm{mL})$ in sodium phosphate after different pressures (700 - $900 \mathrm{MPa}), 25^{\circ} \mathrm{C}$ and treatment times (15 min and $\left.25 \mathrm{~min}\right)$.

\begin{tabular}{|c|c|c|c|c|c|c|c|c|}
\hline \multirow{3}{*}{$\begin{array}{c}\begin{array}{c}\text { Protein concentration } \\
\text { (mg/ml) }\end{array} \\
\text { Treatment time (min) } \\
\text { Pressure (MPa) }\end{array}$} & \multicolumn{4}{|c|}{50} & \multicolumn{4}{|c|}{100} \\
\hline & \multicolumn{2}{|c|}{15} & \multicolumn{2}{|c|}{25} & \multicolumn{2}{|c|}{15} & \multicolumn{2}{|c|}{25} \\
\hline & $\gamma_{c}(\%)$ & $\tau_{c}(\mathrm{~Pa})$ & $\gamma_{c}(\%)$ & $\tau_{c}(\mathrm{~Pa})$ & $\gamma_{c}(\%)$ & $\tau_{c}(\mathrm{~Pa})$ & $\gamma_{c}(\%)$ & $\tau_{c}(\mathrm{~Pa})$ \\
\hline 700 & 0.255 & 13.2 & 0.255 & 9.60 & 0.320 & 60.0 & 0.20 & 116.9 \\
\hline 800 & 0.202 & 25.8 & 0.255 & 19.1 & 0.404 & 420.7 & 0.20 & 859.0 \\
\hline 900 & 0.201 & 44.2 & 0.316 & 29.3 & 0.400 & 652.3 & 0.16 & 1760.5 \\
\hline
\end{tabular}

observed, for all pressures and concentrations tested, while at higher strain the nonlinear behaviour is shown. The results obtained so far are in agreement with those reported by Won Song et al. (2006) [16], who carried out oscillating rheological tests on concentrated $\mathrm{x}$ an than gum solutions. The authors obtained loss modulus curves with similar shape, and this behaviour has been attributed to the occurrence of a strain-overshoot phenomena. When the protein undergoes a stress deformation, the structure shows a resistance up to a certain strain amplitude, leading to an increase of the G' modulus. At higher values of the strain, the protein structure starts to be over-stressed, which results in a decrease of the loss modulus.

As reported in Table 1, the values of $\gamma_{c}$ are independent of the operating pressure while depend on the holding time only at higher protein concentrations. Higher values of the critical strain can be attributed to a higher resistance of the gels which, indeed, is observed at higher holding times for the storage modulus. On the contrary, critical stress increases linearly with the pressure applied at low protein concentration $(50 \mathrm{mg} / \mathrm{mL})$, showing a sudden exponential increase with pressure at higher protein concentration. Our results are in agreement with those of Aguilar et al. (2007) [22] who reported that while the critical stress increases exponentially with the pressure applied, the critical strain is independent on it. Our experimental data demonstrate the relevance of the protein concentration and processing time in defining the limits of the viscoelasticity region, which can be related to the occurrence of protein denaturation.

\subsection{Frequency Sweep Tests}

Frequency sweep tests were carried out utilizing small deformation values, belonging to the linear viscoelasticity region (at strain lower than critical one) in order to evaluate the effect of the $\mathrm{pH}$ on HHP induced denaturation of BSA samples. Protein solutions with a concentration of $100 \mathrm{mg} / \mathrm{mL}$ and different $\mathrm{pH}$ values (6, 7 and 8), were processed at four pressure levels, 600, 700, 800, $900 \mathrm{MPa}$, respectively, for $25 \mathrm{~min}$ and immediately analyzed. BSA gels produced under HHP show a viscoelastic behaviour with both G' and G' 'moduli increasing with frequency. The superiority of storage modulus on loss one indicates that the elastic component is predominant on viscous one in the frequency range tested. At higher pressures both G' and G' moduli are increased thus indicating that the HHP induced gels exhibit more resistance at higher pressure levels (Figures 4(a)-(c)).

Also $\mathrm{pH}$ strongly influences the consistence of the gels: at pH closer to IP higher dependence of both moduli is observed indicating that is higher the resistance of the gels against the deformation applied during rheological characterization. In fact the $\mathrm{pH}$ changes the balance between the electrostatic and the hydrophobic interactions leading to a modified reactivity of the protein towards the effects of the high pressure processes. Furthermore at the isoelectric point the net electric charge of the protein is null, while, when the $\mathrm{pH}$ of the sample is close to the isoelectric point of the protein, the hydrophobic interactions induced by the HHP treatment are not counter-balanced by the repulsive forces and, thus, protein aggregation occurs. At $\mathrm{pH}$ values far from the isoelectric point of the protein, repulsive forces increase and, consequently, the aggregation phenomena are limited. Our results are in agreement with those of Aguilar et al. (2007) [22] who carried out tests on egg yolk and observed that the increase of the $\mathrm{pH}$ caused an increase of loss and storage moduli and, consequently, that in HHP induced albumin gels the denaturation and subsequent aggregation increased. Similarly, Van Camp and Huyghebaert [24] studied the effects of $\mathrm{pH}$ on high pressure induced whey protein gels. The authors found that an increase of the $\mathrm{pH}$ above the IEP (isoelectric point), where whey proteins are negatively charged, results in an increase of the strength of the gel network and in a reduction of the liquid phase not-incorporated in the gel forming network. 


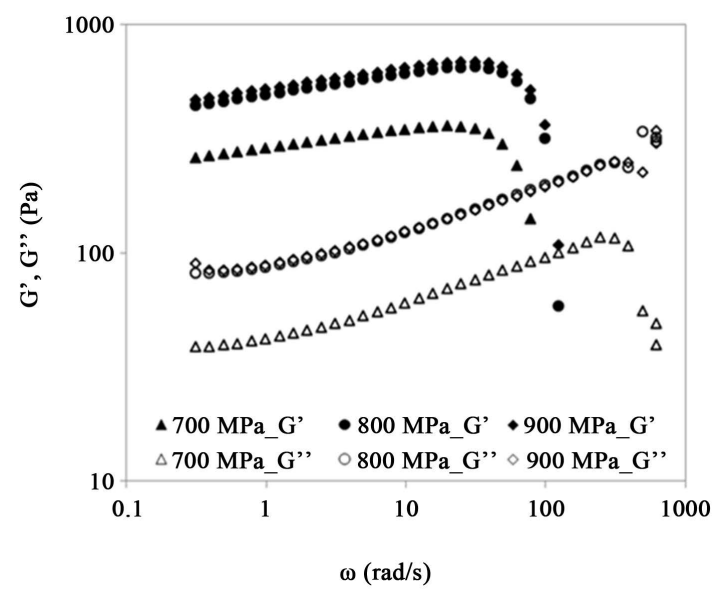

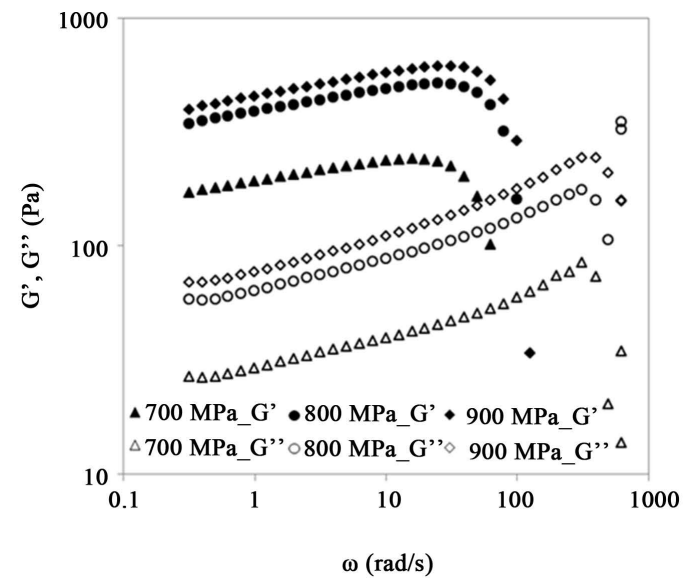

(b)

(a)

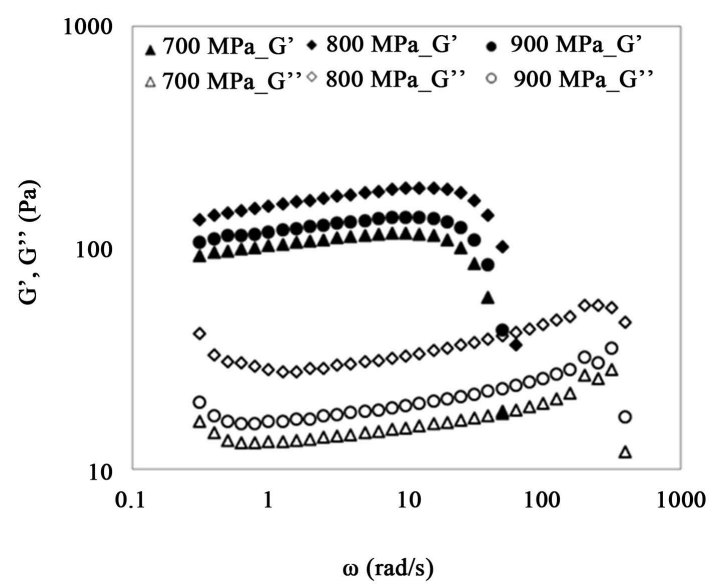

(c)

Figure 4. Frequency sweep tests: storage, G', and loss, G”, moduli as a function of frequency. BSA protein (pH: 8, 100 $\mathrm{mg} / \mathrm{mL}$ ) in sodium phosphate buffer with different $\mathrm{pH}((\mathrm{a}) \mathrm{pH}=6$; (b) $\mathrm{pH}=7$; (c) $\mathrm{pH}=8$ ), treated at different pressure levels (700 MPa, $800 \mathrm{MPa}, 900 \mathrm{MPa}$ ) for $25 \mathrm{~min}$.

\subsection{Temperature Ramp Tests}

Frequency sweep tests were carried induce a partial protein denaturation, the influence of treatment pressure and protein concentration on the transition phase temperature was investigated. In the first case, samples of BSA dissolved in sodium phosphate buffer $(50 \mathrm{mg} / \mathrm{mL})$ were treated at three different pressures of 500, 600 and 700 MPa for $15 \mathrm{~min}$, while different amount of albumin were dispersed in the phosphate buffer in order to assess the effect of protein concentration, namely 12, 25, 50 and $100 \mathrm{mg} / \mathrm{mL}$, and treated under pressure at $500 \mathrm{MPa}$ for 15 min. These mild treatment conditions were set in order to avoid the gelation of samples. At the end of the treatment, the samples were subjected to temperature ramp rheological tests in dynamic regime and the values of G' and G' 'were determined as a function of temperature. The transition phase temperature is defined as the temperature at which the G' modulus starts to increase. Figure 5 reports the curves of the G' of BSA samples treated at different pressures, while Figure 6 shows the curves of the G' of BSA samples with different protein concentration processed at $500 \mathrm{MPa}$ for $15 \mathrm{~min}$.

From the experimental curves the transition phase temperatures were determined and the values are reported in Table 2(a) and Tables 2(b). It can be observed that the higher the pressure applied, the lower the value of the coagulation temperature. At a fixed concentration level of $50 \mathrm{mg} / \mathrm{mL}$, in native protein denaturation occurs at $65.8^{\circ} \mathrm{C}$, while in protein treated at $500 \mathrm{MPa}, 600 \mathrm{MPa}$ and $700 \mathrm{MPa}$ denaturation takes place at $59.2^{\circ} \mathrm{C}, 53.6^{\circ} \mathrm{C}$ and $41.9^{\circ} \mathrm{C}$, respectively, as shown in Table 2(a). Thus, it can be concluded that the main effect of the pressure treatment is to accelerate thermal denaturation, the higher the applied pressure the lower the transition phase 


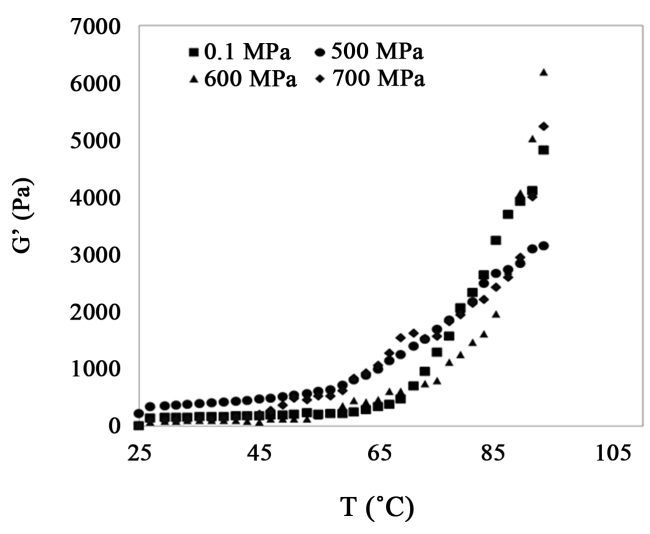

Figure 5. Temperature ramp tests: storage modulus, G' as a function of temperature. BSA protein samples, suspended with a concentration of $50 \mathrm{mg} / \mathrm{mL}$ in sodium phosphate buffer ( $\mathrm{pH}$ : 8), treated at different pressure levels (500 MPa, $600 \mathrm{MPa}, 700 \mathrm{MPa}$ ) for $15 \mathrm{~min}$.

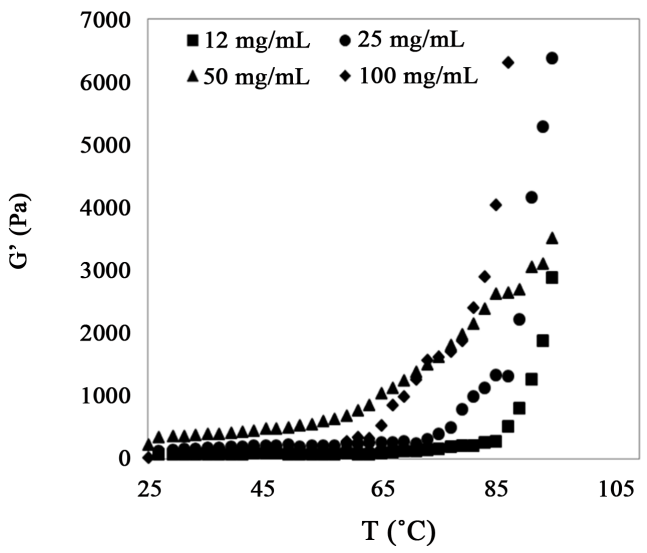

Figure 6. Temperature ramp tests: storage modulus, G', as a function of temperature. BSA protein samples, suspended in sodium phosphate buffer ( $\mathrm{pH}$ : 8) at different concentrations $(12 \mathrm{mg} / \mathrm{mL}, 25$ $\mathrm{mg} / \mathrm{mL}, 50 \mathrm{mg} / \mathrm{mL}, 100 \mathrm{mg} / \mathrm{mL}$ ) treated at a pressure of $500 \mathrm{MPa}$ for $15 \mathrm{~min}$.

Table 2. (a) Effect of protein concentration $(12,25,50$ and $100 \mathrm{mg} / \mathrm{mL}$ ) of BSA treated at $500 \mathrm{MPa}$ for 15 min on transition phase temperature of BSA; (b) Effect of pressure $(500,600$ and $700 \mathrm{MPa})$ of BSA $(50 \mathrm{mg} / \mathrm{mL})$ treated for 15 min on transition phase temperature of BSA.

(a)

\begin{tabular}{cc}
\hline $\mathrm{P}(\mathrm{MPa})$ & $\mathrm{T}\left({ }^{\circ} \mathrm{C}\right)$ \\
\hline 0.1 & $65.8 \pm 3.29$ \\
500 & $59.2 \pm 2.96$ \\
600 & $53.6 \pm 2.68$ \\
700 & $59.2 \pm 2.96$ \\
\hline $\mathrm{C}(\mathrm{mg} / \mathrm{ml})$ & (b) \\
\hline 0.1 & $\mathrm{~T}\left({ }^{\circ} \mathrm{C}\right)$ \\
\hline 500 & $83.9 \pm 4.20$ \\
600 & $75.4 \pm 3.77$ \\
700 & $59.7 \pm 2.99$ \\
\hline
\end{tabular}


temperature. Experimental data demonstrate that, although the processing conditions are unable to induce protein gelation, high pressure treatments cause a significant modification of the BSA protein structure. This effect can be explained by considering that high pressure induces the reversible protein unfolding, which, in turn, can contribute to modify the protein response to other processing methods, including thermal treatments. A similar behaviour is observed with increasing the protein concentration. In fact, as reported in Table 2(b), the transition phase temperature decreases with increasing the protein concentration. For instance, with processing condition of $500 \mathrm{MPa}$ and $15 \mathrm{~min}$, for the BSA sample at $12 \mathrm{mg} / \mathrm{mL}$, the transition phase temperature is equal to $83.9^{\circ} \mathrm{C}$, while it falls down to $56.1^{\circ} \mathrm{C}$ for the BSA sample at $100 \mathrm{mg} / \mathrm{mL}$. Finally, since the interactions among protein macromolecules strongly depend on their concentration in the suspension, the latter, as demonstrated by our experimental data, may also influence the intensity of the structure modification due to high pressure processing by promoting protein denaturation.

\section{Conclusion}

The occurrence and extent of protein denaturation, aggregation and gelation during HHP processing are strictly dependent on the processing conditions as well as the properties of protein solutions, as already observed in thermal treatments. BSA gelation occurs at pressure levels and holding time above well-defined threshold values, which, in turn are mainly controlled by the protein concentration and the $\mathrm{pH}$ of the suspension. BSA samples with high protein concentration and a $\mathrm{pH}$ in the alkaline side of the protein isoelectric point allow lowering the pressure level at which gelation occurs, and the resulting gels formed are more compact, as confirmed with the rheological tests. Moreover, for suspensions with similar protein concentration and $\mathrm{pH}$, the storage $\mathrm{G}$ ' and loss G' moduli increase with increasing the pressure applied. The dependence of the rheological parameters on processing time is weaker and becomes more significant only at high protein concentration $(100 \mathrm{mg} / \mathrm{mL})$. Processing conditions do not play any role in defining the limits of linear viscoelasticity region that is the critical strains. Protein concentration, instead, is the key parameter in determining the dependence of the critical stress on the pressure level. Indeed, at low protein concentration, the critical stress is independent of the pressure applied, while an exponential increase of the critical stress is detected at higher protein concentration. Longer processing times cause an increase of the critical stress, as inferable from the trends of G' and G' moduli, which is more evident at higher protein concentration. Finally, temperature ramp tests carried out on BSA samples treated at pressure level below the threshold value for gelation demonstrates that the structure of BSA can be reversibly damaged, and consequently the transition phase temperature of the protein decreases. The protein concentration plays a key role also in this latter case; the higher the concentration, the more pronounced the thermal denaturation phenomenon.

\section{References}

[1] Pèrez-Mateos, M. and Montero, P. (1997) High-Pressure-Induced Gel of Sardine (Sardinapilchardus) Washed Mince as Affected by Pressure-Time-Temperature. Journal of Food Science, 62, 1183-1188.

http://dx.doi.org/10.1111/j.1365-2621.1997.tb12240.x

[2] Van der Poel, L., Chen, J. and Penagos, M. (2009) Food Allergy Epidemic-Is It Only a Western Phenomenon? Current Allergy \& Clinical Immunology, 22, 3.

[3] Dill, K.A. (1990) Dominant Forces in Protein Folding. Perspectives in Biochemistry, 29, 7133-7155. http://dx.doi.org/10.1021/bi00483a001

[4] Mozhaev, V.V., Heremans, K., Johannes, F., Patrick, M. and Claude, B. (1996) High Pressure Effects on Protein Structure and Function. Proteins: Structure. Function, and Genetics, 24, 81-91. http://dx.doi.org/10.1002/(SICI)1097-0134(199601)24:1<81::AID-PROT6>3.0.CO;2-R

[5] Gross, M. and Jaenicke, R. (1994) Proteins under Pressure. The Influence of High Hydrostatic Pressure on Structure, Function and Assembly of Proteins and Protein Complexes. European Journal of Biochemistry, 221, 617-630. http://dx.doi.org/10.1111/j.1432-1033.1994.tb18774.x

[6] Montero, P. and Pèrez-Mateos, M. (1997) Comparison of Different Gelation Methods Using Washed Sardine (SardinePilchardus) Mince-Effects of Temperature and Pressure. Journal of Agricultural and Food Chemistry, 45, 4612-4618. http://dx.doi.org/10.1021/jf970400e

[7] Messens, W., Van Camp, J. and Huyghebaert, A. (1997) The Use of High Pressure to Modify the Functionality of Food Proteins. Trends in Food Science and Technology, 8, 107-112. http://dx.doi.org/10.1016/S0924-2244(97)01015-7

[8] Richards, F. (1997) Area, Volumes, Packing and Protein Structure. Annual Review of Biophysics and Bioengineering, 6, 
151-176. http://dx.doi.org/10.1146/annurev.bb.06.060177.001055

[9] Speroni, F., Puppo, M.C., Chapleau, N., de Lamballerie, M., Castellani, O., Añón, M.C. and Anton, M. (2005) HighPressure Induced Physicochemical and Functional Modifications of Low-Density Lipoproteins from Hen Egg Yolk. Journal of Agricultural and Food Chemistry, 53, 5719-5725. http://dx.doi.org/10.1021/jf0502808

[10] Cheftel, J. (1992) Effects of High Hydrostatic Pressure on Food Constituents: An Overview. High Pressure and Biotechnology, 224, 195-209.

[11] Jimenez-Colmenero, F., Fernandez, P., Carballo, J. and Fernandez-Martin, F. (1998) High-Pressure-Cooked Low-Fat Pork and Chicken Batters as Affected by Salt Levels and Cooking Temperature. Journal of Food Science, 63, 656-659. http://dx.doi.org/10.1111/j.1365-2621.1998.tb15806.x

[12] Jaenicke, R. (1991) Review: Protein Stability and Molecular Adaptation to Extreme Conditions. European Journal of Biochemistry, 202, 715-728. http://dx.doi.org/10.1111/j.1432-1033.1991.tb16426.x

[13] Schafer, T. and Ring, J. (2008) Epidemiology of Allergic Disease. European Journal of Allergy and Clinical Immunology, 52, 14-22. http://dx.doi.org/10.1111/j.1398-9995.1997.tb04864.x

[14] Galazka, V.B., Ledward, D.A., Sumner, I.G. and Dickinson, E. (1997) Influence of High Pressure on Bovine Serum Albumin and Its Complex with Dextran Sulphate. Journal of Agricultural and Food Chemistry, 45, 3465-3471. http://dx.doi.org/10.1021/jf9700642

[15] Okamoto, M., Kawamura, Y. and Hayashi, R. (1990) Application of High Pressure to Food Processing: Textural Comparison of Pressure- and Heat-Induced Gels of Food Proteins. Agricultural and Biological Chemistry, 54, 183-189. http://dx.doi.org/10.1271/bbb1961.54.183

[16] Song, K.W., Kuk, H.Y. and Chang, G.S. (2006) Rheology of Concentrated Xanthan Gum Solutions: Oscillatory Shear Flow Behaviour. Korea-Australia Rheology Journal, 18, 67-81.

[17] Rastogi, N.K. (2007) Opportunities and Challenges in High Pressure Processing of Foods. Critical Reviews in Food Science and Nutrition, 47, 69-112. http://dx.doi.org/10.1080/10408390600626420

[18] Fernandez-Martin, F., Perez-Mateos, M. and Montero, P. (1998) Effect of Pressure/Heat Combinations on Blue Whiting (Micromesistius poutassou) Washed Mince: Thermal and Mechanical Properties. Journal of Agricultural and Food Chemistry, 46, 3257-3264. http://dx.doi.org/10.1021/jf980040a

[19] Jaenicke, R. (1987) Folding and Associations of Proteins. Progress in Biophysics and Molecular and Biology, 49, 117237. http://dx.doi.org/10.1016/0079-6107(87)90011-3

[20] Silva, J.L. and Welber, G. (1993) Pressure Stability of Proteins. Annual Review of Physical Chemistry, 44, 89-113. http://dx.doi.org/10.1146/annurev.pc.44.100193.000513

[21] Dealy, J.M. and Wissbrun, K.F. (1990) Melt Rheology and Its Role in Plastics Processing. Theory and Applications, 2, 42-100.

[22] Aguilar, J.M., Cordobés, F., Jerez, A. and Guerrero, A. (2007) Influence of High Pressure Processing on the Linear Viscoelastic Properties of Egg Yolk Dispersions. Rheologica Acta, 46, 731-740. http://dx.doi.org/10.1007/s00397-007-0170-2

[23] Apichartsrangkoon, A. (2003) Effects of High Pressure on Rheological Properties of Soy Protein Gels. Food Chemistry, 80, 55-60. http://dx.doi.org/10.1016/S0308-8146(02)00235-2

[24] Van Camp, J. and Huyghebaert, A. (1995) A Comparative Rheological Study of Heat and High Pressure Induced Whey Protein Gels. Lebensmittel-Wissenschaft \& Technologie, 54, 357-364.

http://dx.doi.org/10.1016/0308-8146(95)00040-p 